\title{
Penambahan Fitur Buku Tamu pada Aplikasi Open Source Slims di Perpustakaan STMIK "AMIK BANDUNG"
}

\author{
RHENDY PAJARYANSAH ${ }^{1}$,TEDJO DARMANTO ${ }^{2}$,DANY EKA SAPUTRA ${ }^{3}$
}

\author{
1,2,3 STMIK AMIKBANDUNG \\ Email : rhendy56@gmail.com
}

\begin{abstract}
ABSTRAK
Saat ini pengunjung perpustakaan STMIK "AMIKBANDUNG" mengisi bukutamu dengan cara mengetik data diri secara lengkap baik sebagai member maupun non member. Dan cara tersebut sangat rentan terhadap manipulasi data, sedangkan validasi pengunjung perpustakaan sangat diperlukan untuk rekapituasi laporan pengunjung secara berkala dan pada saat dilakukan akreditasi perpustakaan. Sistem pencatatan pengunjung perpustakaan yang saat ini ada di perpustakaan STMIK "AMIKBANDUNG" memerlukan permbaharuan. Karena dampak dari pembaharuan yang dilakukan sangat baik bagi perpustakaan kampus. Maka dari itu, Penulis melakukan penambahan fitur pada aplikasi open source SLiMS. Desain bukutamu yang nantinya akan dibagi menjadi dua tipe yaitu member dan non member. Mahasiswa yang masuk kedalam kategori member hanya memasukan ID member kedalam form pencatatan buku tamu. Dan untuk non member, tetap mengisi data diri nya secara lengkap. Sehingga memudahkan juga petugas perpustakaan untuk melakukan rekapitulasi pengunjung perpustakaan kampus.
\end{abstract}

Kata kunci: perpustakaan, bukutamu, slims

\begin{abstract}
Currently visitors of STMIK library "AMIK BANDUNG" fill the guest book by typing the complete data by themself as both member and non member. And the way is very susceptible to data manipulation, whereas validation of library visitors is necessary for recapituation of visitor reports on a regular basis and at the time of library accreditation. The library visitor recording system currently in the STMIK library "AMIK BANDUNG" requires a renewal. Because the impact of the renewal is done very well for the campus library. Therefore, the author made additional features in open source SLiMS applications. The design of your guestbook will be divided into two types namely member and non member. Students who enter into the category of members just enter the ID member into the guestbook recording form. And for non members, still fill his complete data. So it makes it easier for librarians to recapitulate campus library visitors.
\end{abstract}

keywords : library, guestbook, slims 


\section{PENDAHULUAN}

Perpustakaan Perguruan Tinggi merupakan unit penunjang untuk melakukan pendidikan, penelitian dan pengabdian kepada masyarakat berdasarkan PP No.30 tahun 1990 pasal 34 PPT (Perpustakaan Perguruan Tinggi). Sebagai komponen penting dalam eksistensi perpustakaan, maka perpustakaan harus menyediakan fitur buku tamu untuk medata siapa saja yang mengunjungi perpustakaan. Dan pemustaka pun wajib mengisi buku tamu tersebut, untuk keperluan perpustakaan. Data jumlah pengunjung perpustakaan juga masuk kedalam penilaian dalam akreditasi perpustakaan, sebagai penilaian pelayanan perpustakaan terhadap pemustaka. Maka untuk memenuhi kebutuhan tersebut, perpustakaan harus menyediakan satu fitur di dalam aplikasi SLiMS yang dapat mencatatat pengunjung perpustakaan. Dan juga mengatur rekapitulasi pengunjung secara berkala, yang nantinya dapat dijadikan bahan evaluasi terkait eksistensi perpustakaan.

\section{LANDASAN TEORI}

\subsection{SLiMS (Senayan Library Management System)}

SLIMS digunakan pertama kali di Depertement Pendidikan. Perkembangannya di lakukan oleh CSD (Senayan Devolopers Comunity). Senayan adalah aplikasi berbasis web untuk memenuhi kebutuhan automasi perpustakaan skala kecil hingga skala besar yang merupakan Open Source dengan mempertimbangkan cross-platform (Manual SLiMS Versi 3 Stable 15, 2010).

Teknologi AJAX (Asynchronous JavaScript And XML) digunakan untuk peningkatan Interaktifitas, sehingga diharapkan bisa memiliki tampilan seperti aplikasi berbasis desktop. Pada Senayan ada penambahan fitur PhpThumb dan Simbio. Senayan dapat di modifikasi dan di distribusi kembali karena sudah dilisensikan dibawah GPLv3. (Yupiter,2018).

SliM secara dasar memiliki 8 modul, modul itu sendiri berisi fitur-fitur pendukung yang dapat digunakan oleh petugas perpustakaan untuk memudahkan dalam mengelola perpustakaan sesuai dengan prosedur yang dipakai.

a. Modul Blibliografi

Didalam modul ini berisi fitur untuk mengelola koleksi perpustakaan, seperti buku, majalah, jurnal, CD, dll.

b. Modul circulation 
Modul ini berisi fitur mengenai pendataan buku ataupun koleksi yang dipinjam oleh mahasiswa maupun anggota, selain itu juga terdapat fitur waktu pengembalian koleksi yang dipinjam.

c. Modul master_file

Didalamnya terdapat Fitur untuk mengatur referensi dari dari data yang didapatkan dan akan dipublikasikan. Baik data barupa data jurnal, data buku, dan data koleksi perpustakaan lainnya.

d. Modul membership

Modul ini adalah untuk mengatur sistem keanggotaan perpustakaan.

e. Modul reporting

Modul yang dapat digunakan untuk mendapatkan informasi serta mengelola laporanlaporan mengenai anggota perpustakaan, koleksi perpustakaan, daftar anggota yang meminjam koleksi perpustakaan dan juga dapat merekap laporan mengenai perpustakaan.

f. Modul serial_control

Fitur untuk mengelola serial dari koleksi perpustakaan sebelum di publikasikan seperti, titel buku, subjek buku, author dan ISBN/ISSN.

g. Modul system

Segala bentuk konfirgurasi dari sistem aplikasi terdapat dalam modul ini. Contoh fitur dari modul ini adalah mengelola sistem user dan backup data aplikasi SLiMS.

h. Modul Stock_take

Didalam modul ini terdapat fitur untuk memproses ketersediaan stok dari koleksi perpustakaan. Dan juga informasi dari jumlah maupun macam-macam koleksi perpustakaan.

\subsection{Skema Penambahan Modul Buku tamu}

Modul buku tamu adalah modul yang diperlukan untuk mengelola pengunjung perpustakaan. Untuk menambahkan modul baru kedalam SLiMS terdapat langkah-langkah yang harus dilakukan seperti pada Gambar 1.

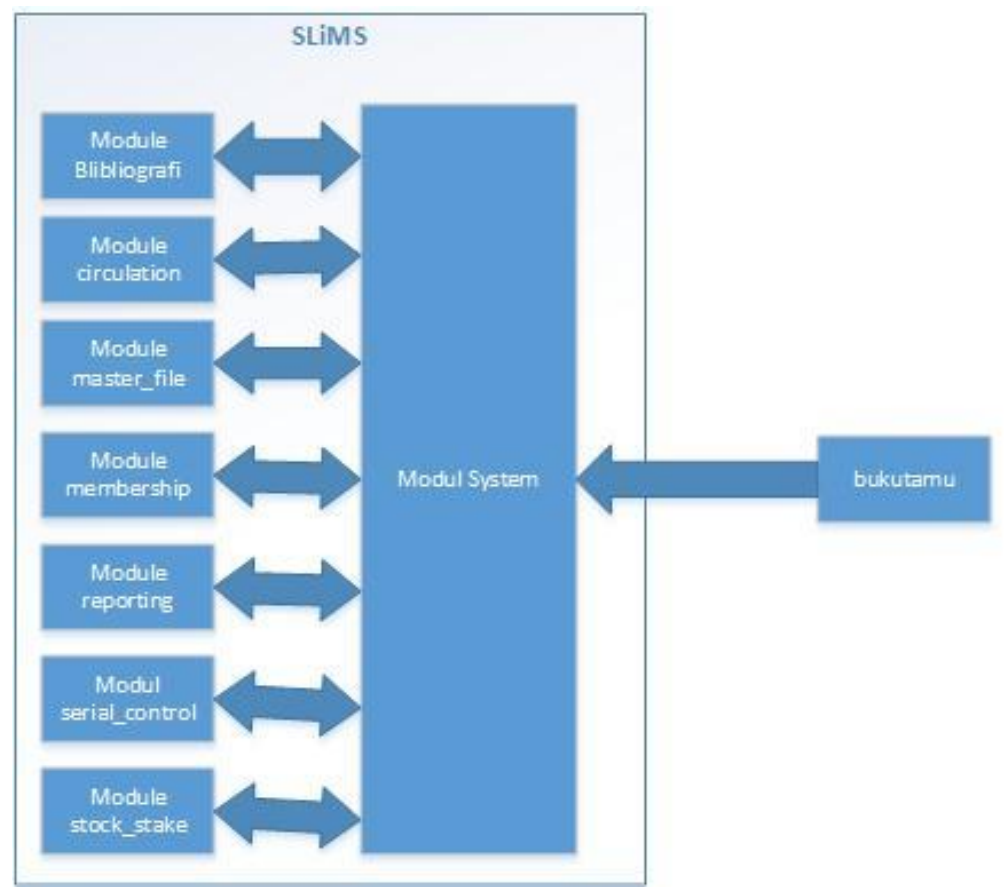

Gambar 1. Skema Penambahan Modul Buku Tamu 
Berikut ini keterangan dari skema tersebut adalah :

a. Jika akan menambahkan modul baru ke dalam SLiMS, maka harus ditambahkan juga nama dari modul yang akan dibuat ke menu module, dan menu tersebut ada didalam modul system.

b. Karena modul buku tamu berfokus kepada data pengunjung, maka harus diintegrasikan dan direlasikan dengan tabel yang ada di modul membership. Karena modul membership terdapat data anggota perpustakaan.

c. Fitur yang terdapat dalam buku tamu adalah fitur pencatatan pengunjung yang dibedakan menjadi dua tipe pengunjung, yaitu member dan non member.

d. Untuk menjalankan modul pada buku tamu harus dilakukan konfirgurasi serta coding untuk memaksimalkan kinerja buku tamu pada aplikasi SliM

\section{ANALISIS DAN PERANCANGAN}

\subsection{Prosedur Sistem yang Berjalan}

Gambar 2 dibawah ini mengambarkan flow chart dari sistem yang sedang berjalan saat ini. Pengunjung harus input dahulu data dirinya secara lengkap, dan secara manual di aplikasi yang saat ini tersedia. Dan aplikasi saat ini belum ada validasi dari inputan yang diisi oleh pengunjung.

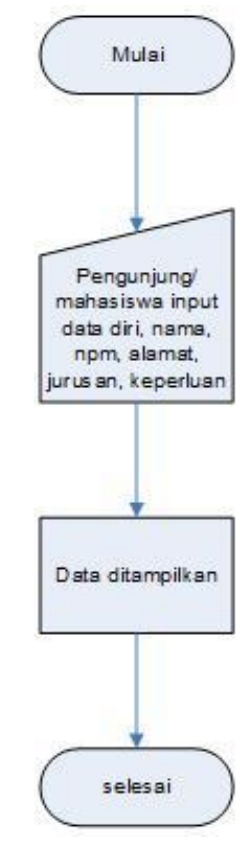

\section{Gambar 2. Flow chart sistem yang sedang berjalan}

Pada Gambar 3 diatas merupakan flow chart sistem peminjaman buku yang saat ini dipakai. Syarat utama bagi yang ingin meminjam buku di perpustakaan, mahasiswa diharuskan memiliki kartu anggota perpustakaan. Untuk mendapatkan kartu perpustakaan, mahasiswa harus mengisi form pendaftaran yang diberikan oleh petugas perpustakaan. Setelah mahasiswa mengisi semua form pendaftaran yang telah diisi secara lengkap dan melengkapi administrasi lainnya. Maka petugas akan mencetak kartu anggota, dan mahasiswa dapat meminjam buku perpustakaan. Dan pada saat meminjam, petugas akan mencatat buku apa 
saja yang di pinjam ke dalam excel dan dicatat di dalam buku yang dipinjam, tanggal meminjam dan tanggal pengembalian buku.
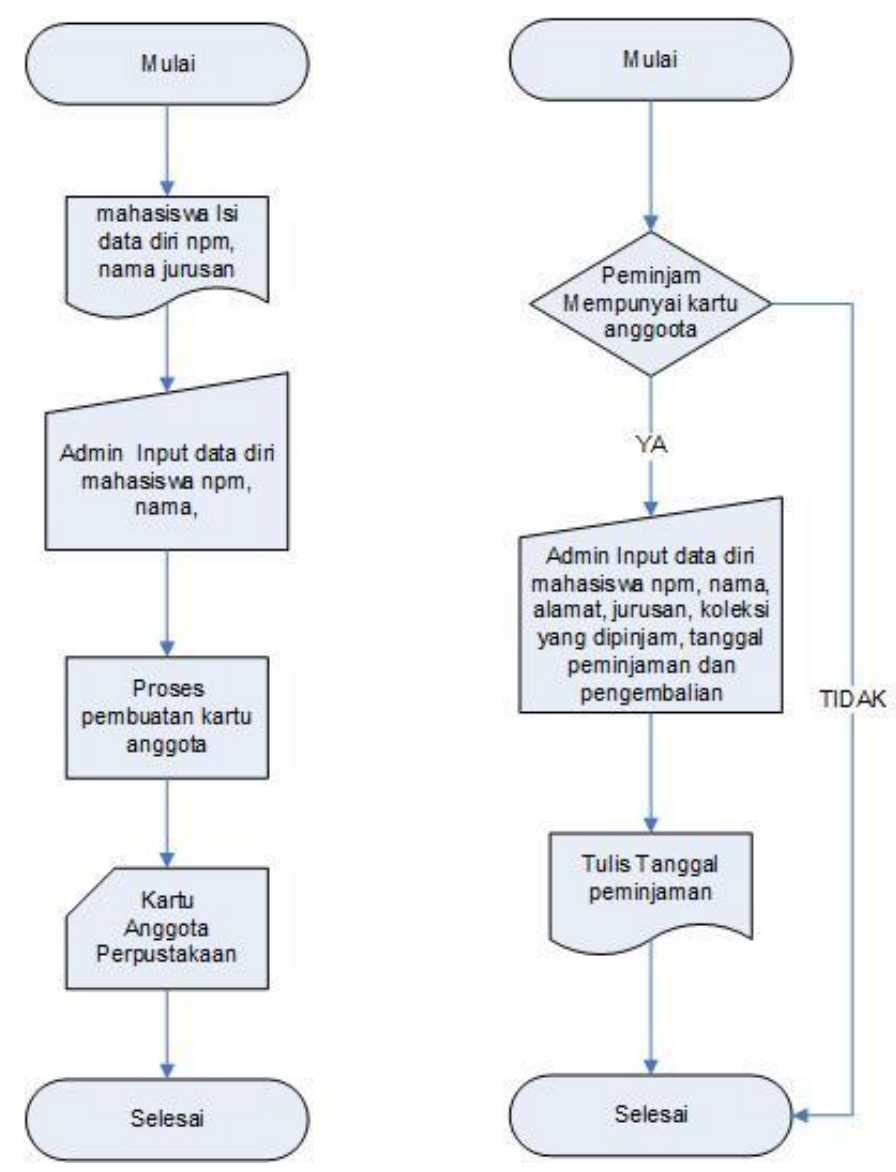

Gambar 3. Flow chart pembuatan kartu anggota dan peminjaman

\subsection{Flow chartBuku Tamu}

Flow chart dari fitur buku tamu yang ditambahkan kedalam aplikasi SliMS dijabarkan pada Gambar 4. Alur dari pencatatan buku tamu ini, mahasiswa cukup mengisi NPM pada kolom yang disediakan. Jika NPM tersebut terdaftar didalam sistem dan data yang dimasukan telah tervalidasi, maka data akan masuk kedalam aplikasi dan buku tamu terisi secara otomatis.

\subsection{Perancangan Flow chart Peminjaman}

Alur peminjaman untuk mahasiswa yang telah terdaftar di dalam aplikasi digambarkan pada Gambar 5. Setelah mahasiswa mengisi aplikasi buku tamu sebagai pencatatan bahwa mahasiswa tersebut telah mengunjungi perpustakaan untuk meminjam buku. Dilanjutkan pencatatan peminjaman oleh petugas perpustakaan, inputan yang dilakukan oleh petugas perpustakaan cukup menginput kode buku yang dipinjam oleh mahasiswa. 


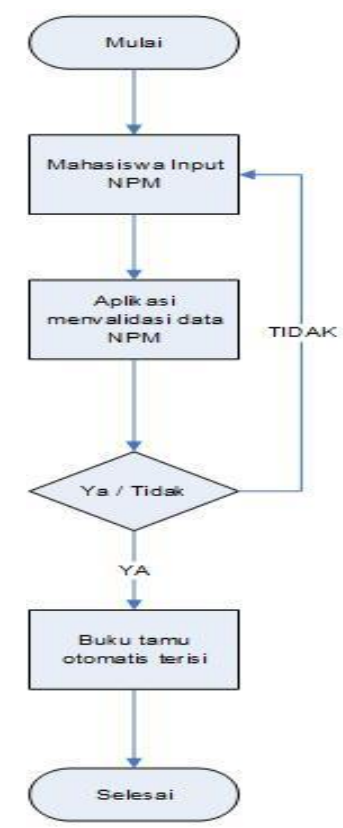

\section{Gambar 4. Flow chartbuku tamu}

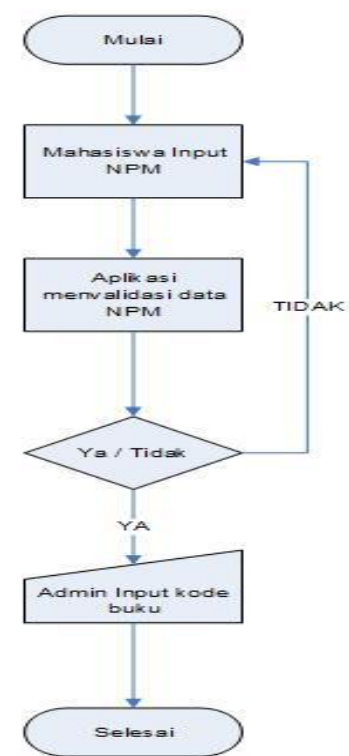

Gambar 5. Flow chartpeminjaman

\subsection{Data Flow Diagram Yang Direncanakan}

Berikut ini merupakan pengambaran aliran data dari sistem yang direncanakan : 


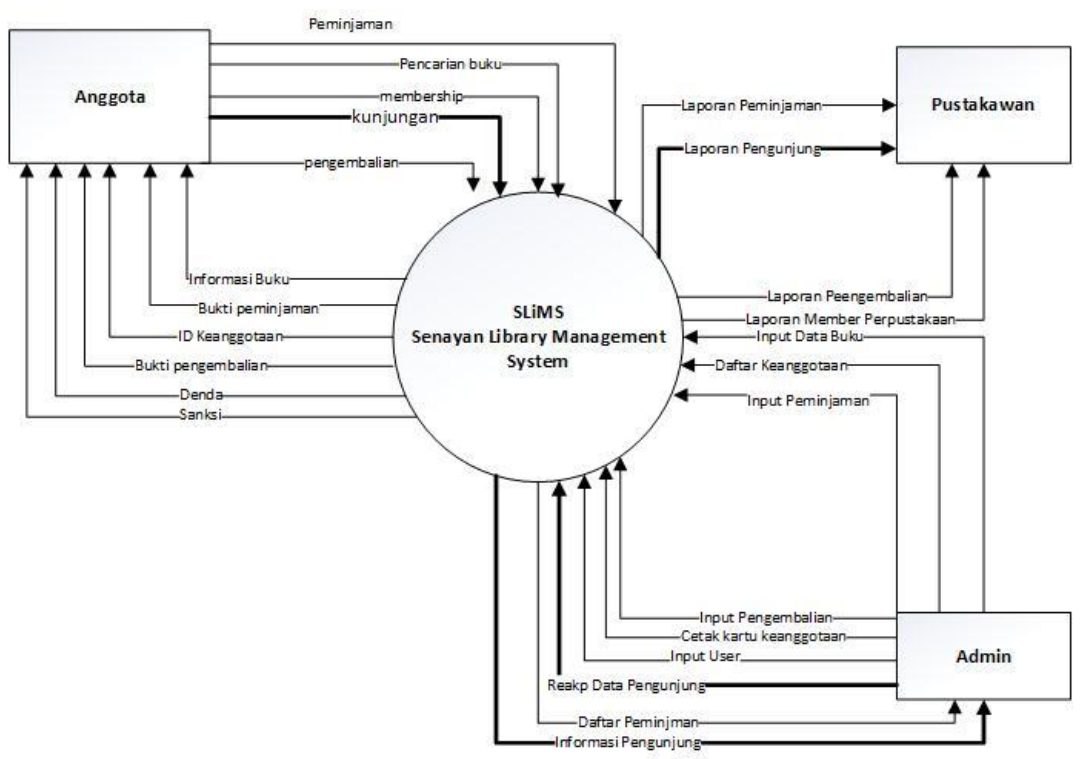

Gambar 6. DFD SLiMS level 0

Tabel 1. Aliran Data DFD level 0

\begin{tabular}{clll} 
No Proses & \multicolumn{1}{c}{ Proses } & \multicolumn{1}{c}{ Data In } & \multicolumn{1}{c}{ Data Out } \\
0 & SLiMS & Data peminjaman & Daftar peminjaman \\
& Senayan & Membership & Laporan membership \\
& Library & Data pengunjung & Informasi pengunjung \\
& Management & Data pengembalian & Laporan pengembalian \\
& System & Data pencarian buku & Informasi buku \\
& & Input data buku & Bukti peminjaman \\
& Daftar keanggotaan & ID keanggotaan \\
& Input peminjaman & Denda \\
& Input pengembalian & Sanksi \\
& Rekap data pengunjung & Laporan pengunjung \\
& Cetak kartu keanggotaan & Bukti pengembalian \\
& Input user & Laporan peminjaman
\end{tabular}

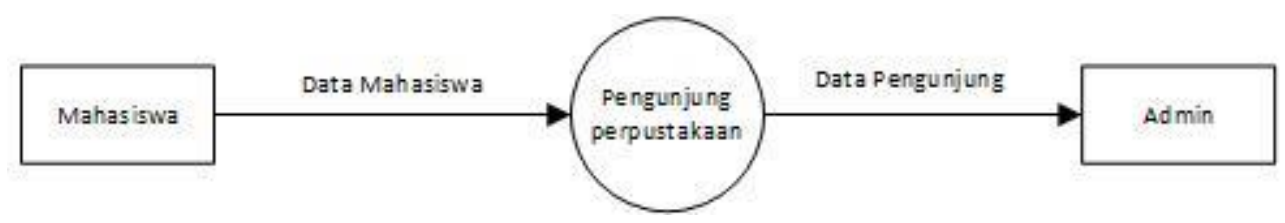

Gambar 7. DFD SLiMS level 0

Tabel 2. Aliran data pencatatan buku tamu DFD level 1

\begin{tabular}{clll} 
No Proses & \multicolumn{1}{c}{ Proses } & \multicolumn{1}{c}{ Data In } & \multicolumn{1}{c}{ Data Out } \\
0 & Pengunjung & Input Data Mahasiswa & Laporan Data Pengunjung \\
& Perpustakaan & & Perpustakaan
\end{tabular}




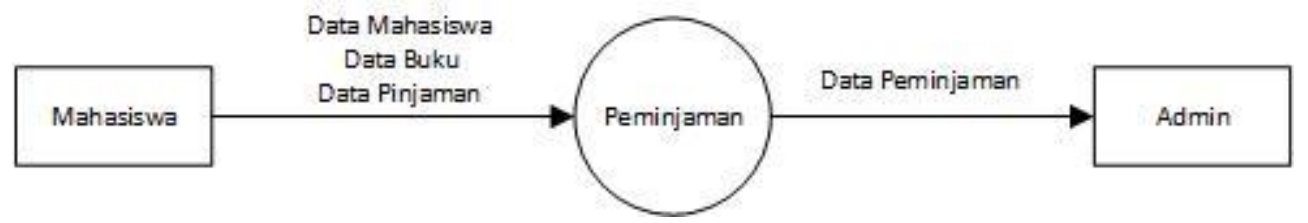

Gambar 8. DFD Peminjaman level 1

Tabel 3. Aliran data peminjaman DFD level 1

\begin{tabular}{clll} 
No Proses & \multicolumn{1}{c}{ Proses } & \multicolumn{1}{c}{ Data In } & \multicolumn{1}{c}{ Data Out } \\
0 & Peminjaman & Input Data Mahasiswa & Laporan Data Peminjam \\
& & Input data Buku & Buku \\
& & Input Tanggal Peminjaman & Laporan tanggal \\
& Input Tanggal Pengembalian & peminjaman \\
& & Laporan tanggal \\
& & pengembalian
\end{tabular}

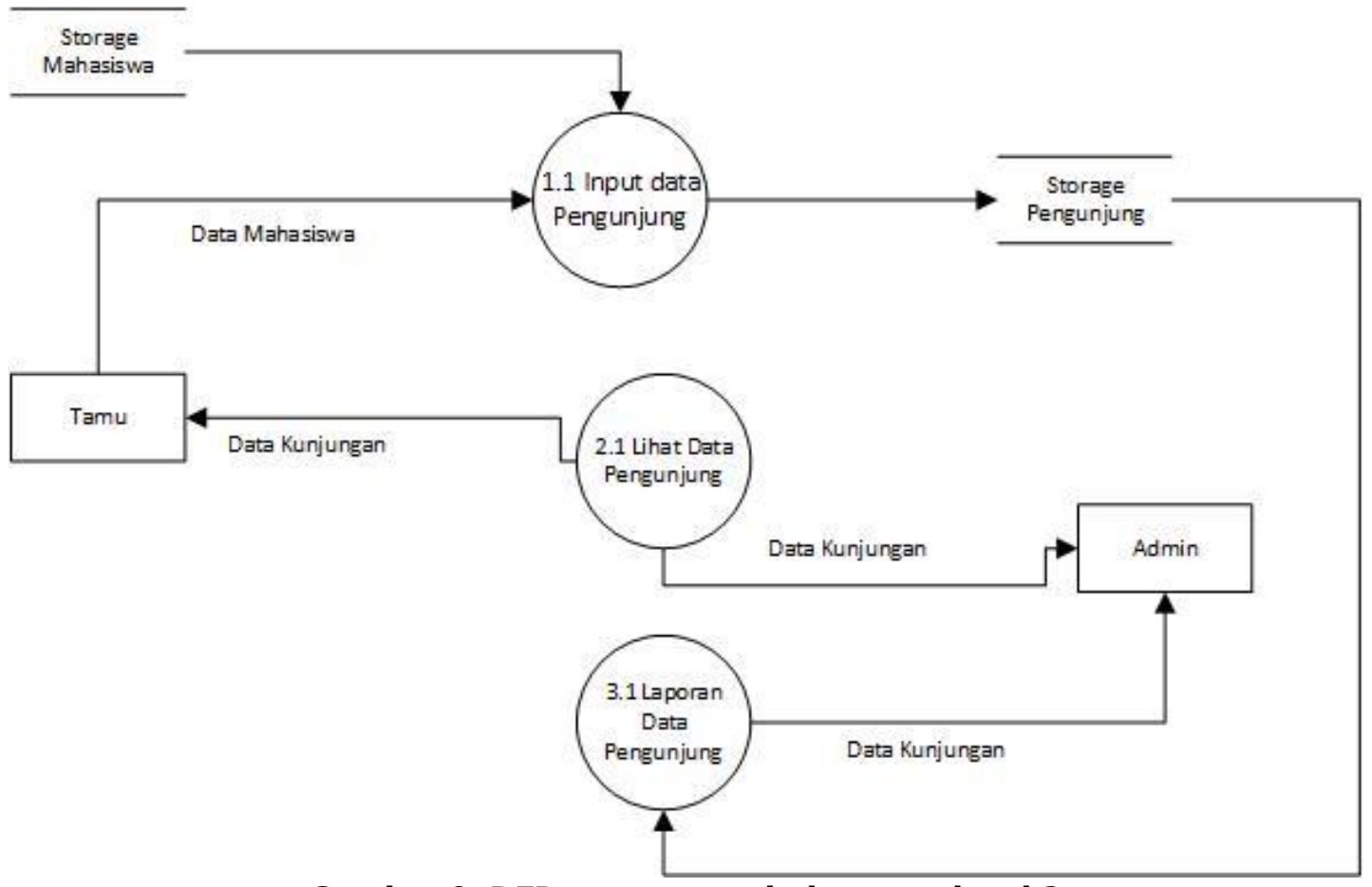

Gambar 9. DFD pencatatan buku tamu level 2

Tabel 3. Aliran Data Pencatatan pengunjung DFD level 2

\begin{tabular}{clll} 
No Proses & Proses & \multicolumn{1}{c}{ Data In } & \multicolumn{1}{c}{ Data Out } \\
1.1 & Input data & Input Data pengunjung & Laporan Data pengunjung \\
& pengunjung & perpustakaan & perpustakaan \\
2.1 & Lihat Data & Data Kunjungan & Laporan data kunjungan \\
& Pengunjung & Perpustakaan & perpustakaan \\
3.1 & Laporan & Data pengunjung & Laporan Data pengunjung \\
& Data & Perpustakaan & perpustakaan \\
& Pengunjung & & \\
& &
\end{tabular}


Penambahan Fitur Buku Tamu pada Aplikasi Open Source Slims di Perpustakaan STMIK "AMIK BANDUNG"

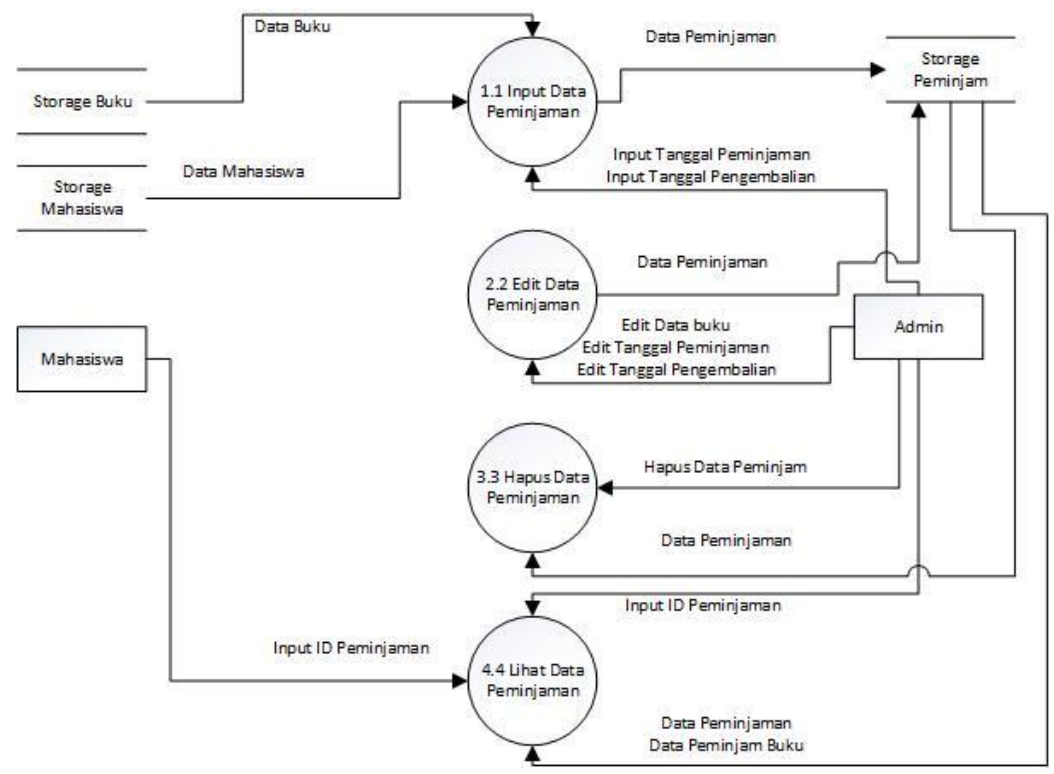

Gambar 10. DFD Peminjaman level 2

Tabel 4. Aliran Data peminjaman DFD level 2

No Proses

1.1

2.2

3.3

4.4
Proses

Input data peminjaman

Edit data peminjaman

\section{Hapus data} peminjaman Lihat Data Peminjaman
Data In

Input Data Peminjam

Input data buku

Input tanggal peminjaman

Input tanggal

pengembalian

Edit data buku yang

dipinjam

Edit tanggal peminjaman

Edit tanggal pengembalian

Hapus data peminjaman

Input ID Peminjaman

Data Out

Laporan Data

peminjaman

Laporan data

peminjaman

Laporan Data

peminjaman

Laporan data

peminjaman

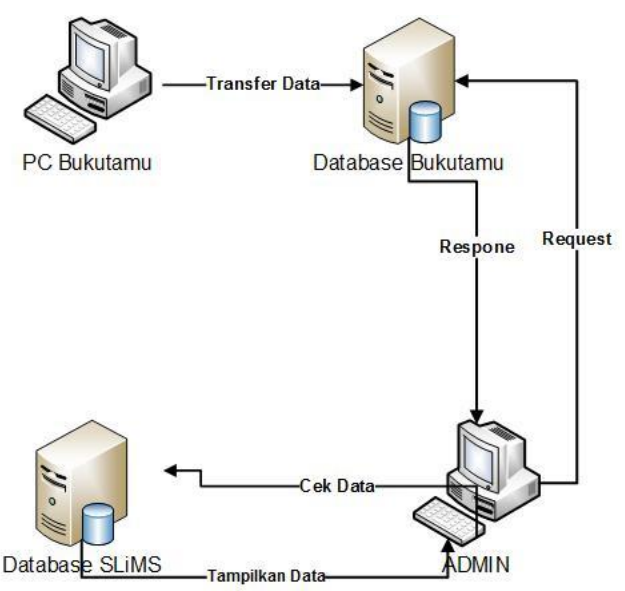

Gambar 11. Alur sistem buku tamu 
Alur sistem buku tamu yang digunakan untuk perpustakaan dan diintegrasikan dengan aplikasi SLiMS yang sudah ada. Berikut ini adalah penjelasan dari Gambar 11 :

a. PC buku tamu disediakan oleh perpustakaan untuk mahasiswa input NPM dan non member input data diri.

b. Ketika proses pengisian telah selesai, maka dilakukan validasi data. Untuk mendeteksi data yang diinputkan apakah sudah sesuai atau belum.

c. Jika data sudah sesuai, maka data masuk kedalam database buku tamu

d. Setelah data masuk kedalam database, maka admin dapat melakukan pengolahan data.

\subsection{Entity Relationship Diagram(ERD)}

Setelah didapatkan rancangan DFD maka penulis melanjutkan untuk merancang keterhubungan tiap entitas didalam aplikasi. Dalam aplikasi ini penulis akan menjelaskan ERD sebelum ditambahkan modul buku tamu dan juga entitas sesudah ditambahkan modul buku tamu. Pada entitas ini penulis memakai database yang telah dipakai oleh aplikasi SLiMS, penulis hanya menambahkan tabel kedalam database tersebut dan dilakukan query untuk menghubungkan antar tabel.

Dalam aplikasi ini database yang digunakan diberi nama senayandb.sql. Ada 3 tabel utama yang harus diketahui pada saat menambah modul buku tamu yaitu, tabel member, mst_member_type, dan visitor_count. Alur sebelum ditambahkan buku tamu, semua data baik member maupun non-member harus ada didalam tabel member. Dan pada saat ditambahkan modul buku tamu harus ditambahkan satu tabel untuk menyimpan data non-member, hal ini dilakukan untuk meminimalisir kesalahan petugas dalam rekap data pengunjung maupun peminjam buku. Dalam modul buku tamu penulis menambahkan tabel visitor, yang isinya disesuaikan dengan kebutuhan perpustakaan.

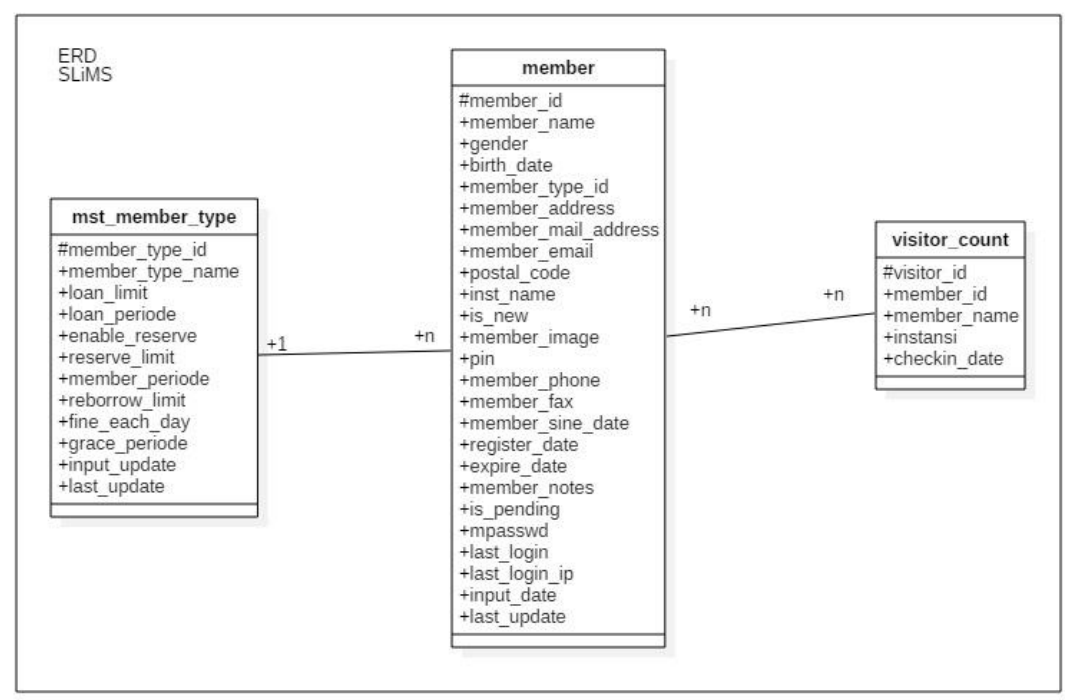

Gambar 12. ERD aplikasi SliMS 


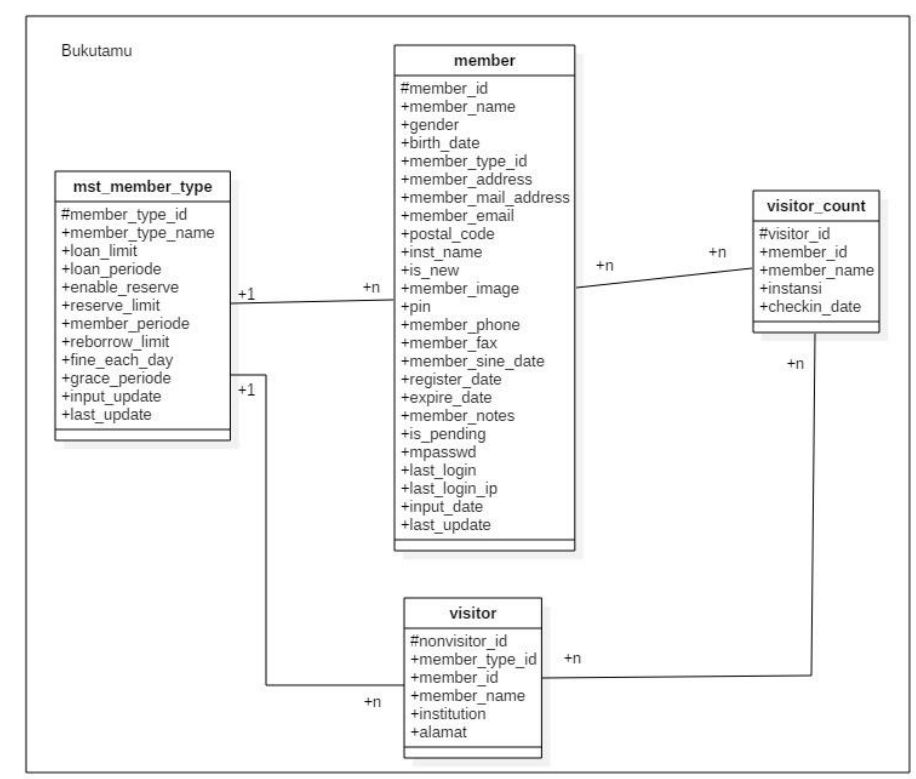

Gambar 13. ERD aplikasi buku tamu

\section{IMPLEMENTASI DAN PENGUJIAN}

\subsection{Spesifikasi Perangkat Keras dan Perangkat Lunak}

Pada talel 6 dan table 7 adalah spesifikasi hardware dan software yang digunakan pada pembangunan program buku tamu.

Tabel 6. Tabel Spesikasi Hardware

\begin{tabular}{|l|l|l|}
\hline No & Perangkat keras & Keterangan \\
\hline 1 & Lenovo & $80 E 1 \mathrm{A6}$ \\
\hline 2 & RAM & $2148 \mathrm{MB}$ \\
\hline 3 & Processor & $A M D A 61,8 \mathrm{GHz}$ \\
\hline 4 & Display VGA & $1024 \mathrm{MB}$ \\
\hline
\end{tabular}

Tabel 7. Tabel Spesifikasi Software

\begin{tabular}{|l|l|l|}
\hline No & Perangkat Lunak & Keterangan \\
\hline 1 & Sistem Operasi & Window 7 \\
\hline 2 & Bahasa Pemrograman & PHP 5.6.32 \\
\hline 3 & Web Server & Apache 2.4.29 \\
\hline 4 & Database Server & MySQL 5.0.11 \\
\hline 5 & Web Browser & Chrome \\
\hline
\end{tabular}

\subsection{Implementasi Interface}

4.2.1 Tampilan Input Data Kunjungan Member 


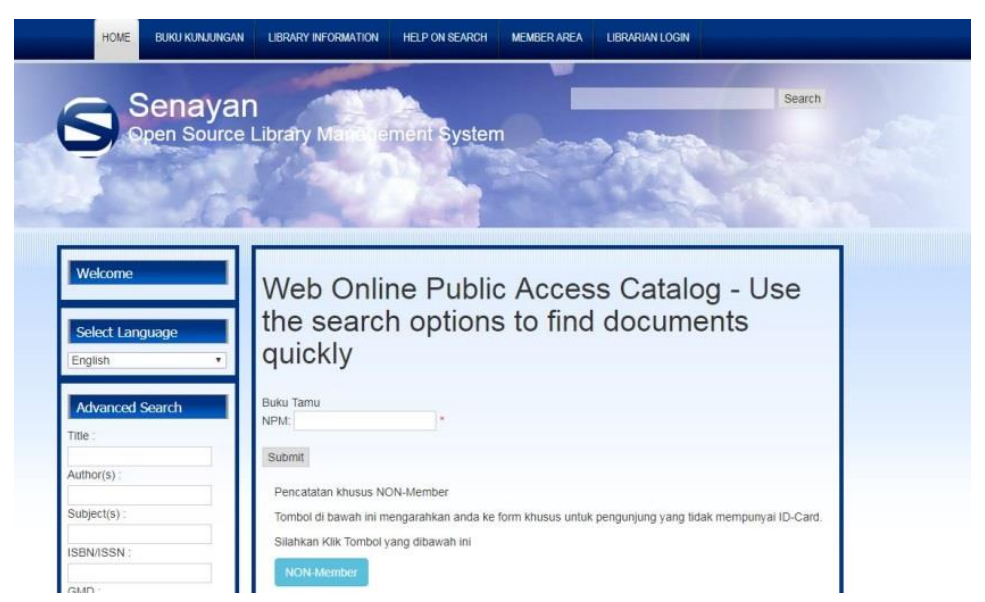

Gambar 14. Tampilan input data member

4.2.2 Tampilan Input Data Kunjungan Non Member

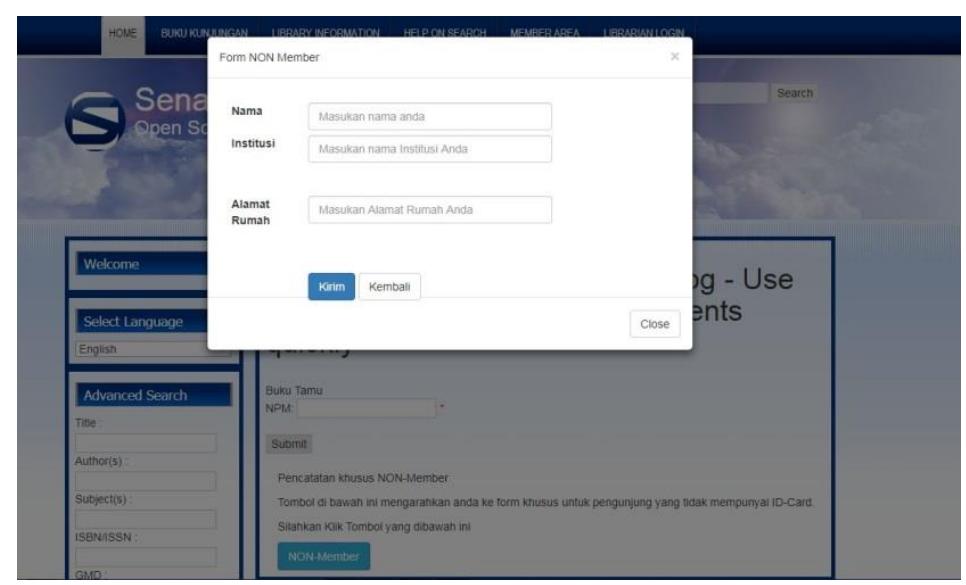

Gambar 15. Tampilan input data non member

4.2.3 Tampilan Data Kunjungan Member

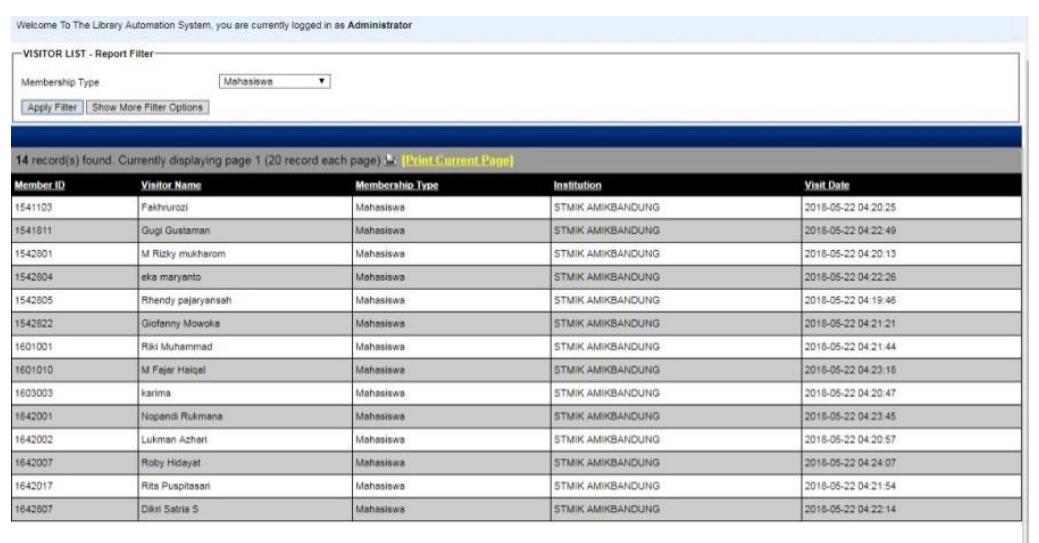

Gambar 16. Tampilan data kunjungan member 


\subsubsection{Tampilan Data Kunjungan Non Member}

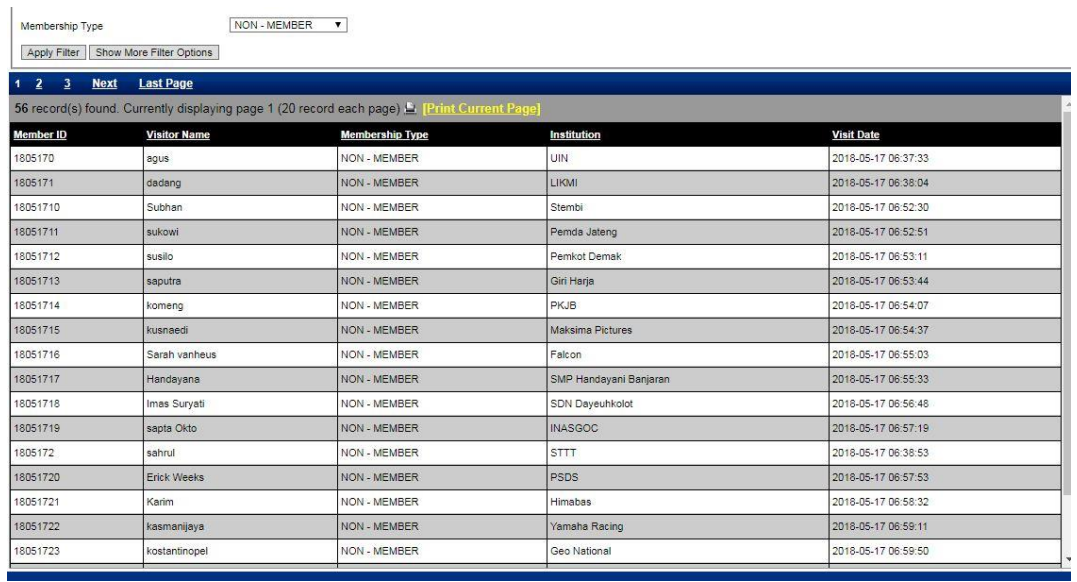

\section{Gambar 17. Tampilan kunjungan nonmember}

\subsection{Pengujian Validasi SqI Injection}

Pengujian validasi sql injection dilakukan dengan prosedur yang jelaskan lewat flow chart dibawah ini. Data yang diinput kedalam kolom yang disediakan apakah sesuai dengan kriteria aplikasi atau tidak, jika tidak maka akan masuk ke fase selanjutnya untuk dilakukan scanning. Hasil scanning tersebut jika ditemukan database error maka aplikasi vulnerable atau masih ada celah, jika tidak ada error maka aplikasi non vulnerable atau sudah tidak ada celah sql injection. Dan jika dari awal aplikasi sudah tervalidasi, maka aplikasi dan database aman.

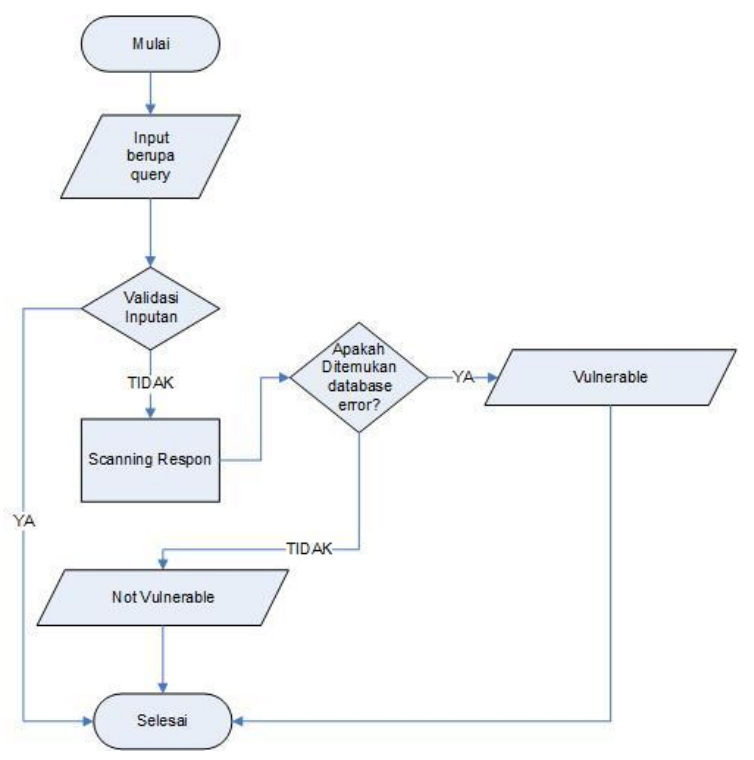

Gambar 18. Prosedur pengujian SQL Injection

Testing pada inputan form, jika inputan terindikasi sql injection ataupun pengisian data tidak sesuai dengan karakter yang diharapkan maka akan ditandai dengan tanda ( $\mathrm{v}$ ) . dan jika data inputan tersebut dapat masuk kedalam database maka ditandai dengan tanda (x). 
Tabel 8. Validasi data member

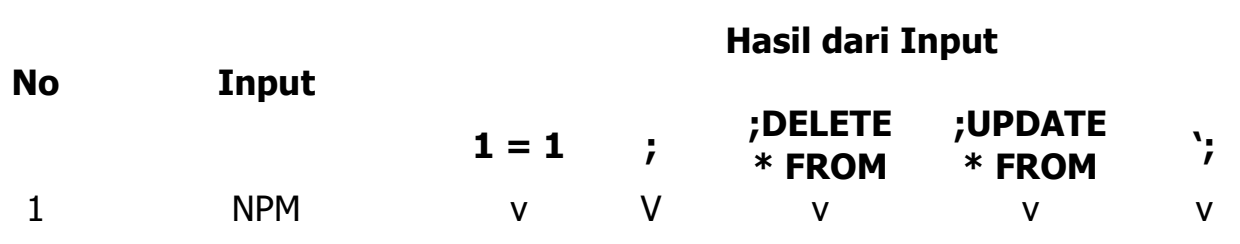

Tabel 9. Validasi data non member

\begin{tabular}{|c|c|c|c|c|c|}
\hline \multirow{2}{*}{ No } & \multirow{2}{*}{ Input } & \multicolumn{4}{|c|}{ Hasil dari Input } \\
\hline & & $1=1$ & ; & $\begin{array}{c}\text {;DELETE } \\
* \text { FROM }\end{array}$ & $\begin{array}{l}\text {;UPDATE } \\
\text { * FROM }\end{array}$ \\
\hline 1 & Nama & $\mathbf{v}$ & $\mathbf{v}$ & $\mathbf{v}$ & $\mathbf{v}$ \\
\hline 2 & Instansi & $\mathbf{v}$ & $\mathbf{v}$ & $\mathbf{v}$ & $\mathbf{v}$ \\
\hline 3 & Alamat & $\mathbf{v}$ & v & $\mathbf{v}$ & $\mathbf{v}$ \\
\hline
\end{tabular}

Pada proses inputan ini dilakukan sampling untuk pengisian data didalam form yang telah disediakan. Dan data yang diisikan berupa script query maupun script HTML. Dengan hasil testing sebagai berikut :

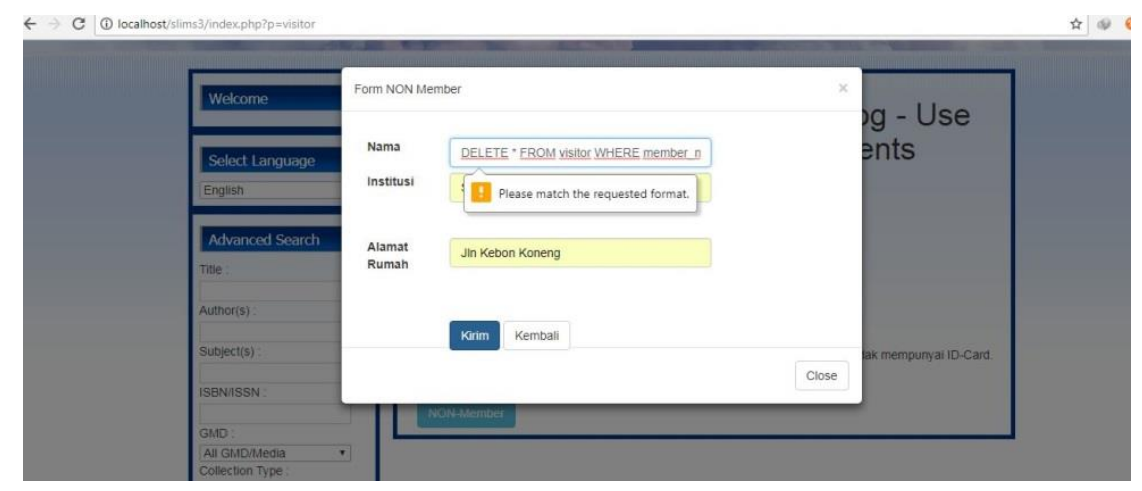

Gambar 20. Validasi input nama

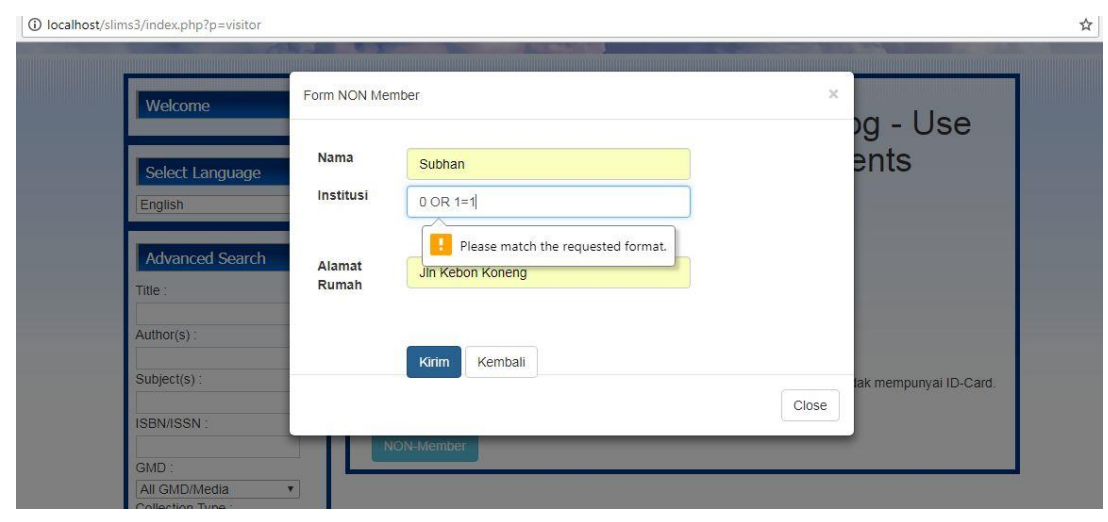

Gambar 21. Validasi input institusi 


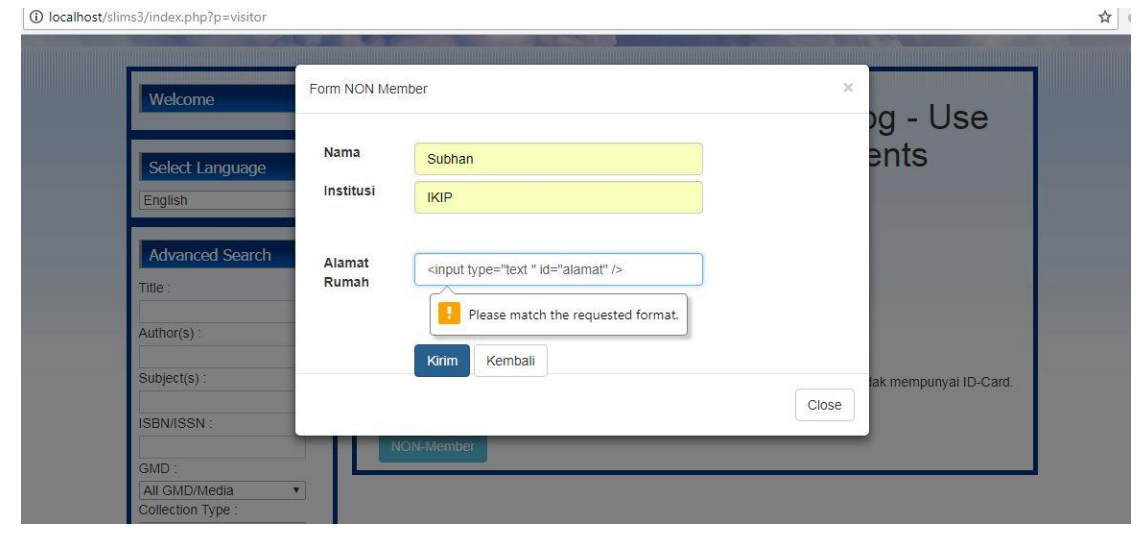

Gambar 22. Validasi input alamat

\section{KESIMPULAN}

Aplikasi buku tamu ini adalah untuk melengkapi kebutuhan aplikasi yang digunakan oleh perpustakaan kampus. Saat ini kampus memakai aplikasi SLiMS. Dan di dalam aplikasi buku tamu ini dibagi menjadi 2 typemember, pertama member yang terdaftar didalam aplikasi dan non member adalah pengunjung yang tidak terdaftar di dalam aplikasi. Di buatnya aplikasi buku tamu ini tujuannya untuk memudahkan mahasiswa maupun yang bukan mahasiswa dalam mengisi buku tamu pada saat mengunjungi perpustakaan. Aplikasi yang dibuat harus disesuaikan dengan aplikasi yang sudah ada yaitu SLiMS. Aplikasi buku tamu ini memakasi database dari SLiMS dan disesuaikan dengan menambah beberapa tabel untuk kebutuhan data pengunjung perpustakaan.

\section{DAFTAR RUJUKAN}

Peraturan Pemerintah No 24 Tahun 2014, Peraturan Pemerintah, no. PELAKSANAAN UNDANGUNDANG NOMOR 43 TAHUN 2007, p.60, 2014.

UU No.43 Tahun 2007 Pasal 1 ayat 9, UU PERPUSTAKAAN, no. TENTANG PERPUSTAKAAN, p. 40, 2007.

SLiMS, Manual SLiMS Versi 3 Stable 15, no. SLiMS Matoa, p. 137. 